
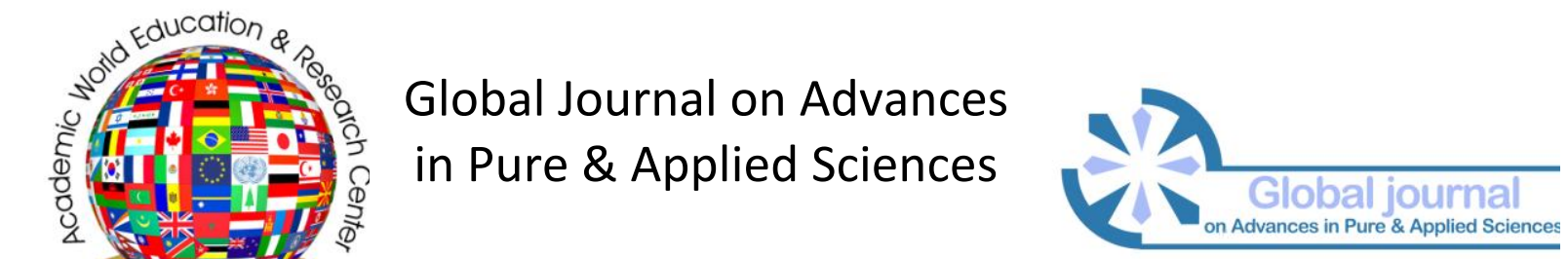

Issue 7 (2016) 137-144

Selected Paper of 2nd World Conference on Health Sciences (H-SCl 2015)

30 April-02 May 2015 Efes Surmeli Hotel \& Convention Center - İzmir, Kusadası, Turkey

\title{
Human Thermal Comfort Situation in the Goller (Lakes) District of Turkey
}

Yuksel Guclu *, Faculty of Education, Department of Social Studies Education, Sakarya University, Hendek, Sakarya, 54300, Turkey.

\section{Suggested Citation:}

Guclu, Y. (2016). Human Thermal Comfort Situation in the Goller (Lakes) District of Turkey, Global Journal on Advances in Pure \& Applied Sciences. [Online]. 07, pp 137-144. Available from: www.propaas.eu

Received November 13, 2014; revised December 06, 2014; accepted March 13, 2015.

Selection and peer review under responsibility of Prof. Dr. Fahrettin Sadıkoglu, Near East University. (C)2016 Academic World Education \& Research Center. All rights reserved.

\begin{abstract}
In this study, the determination of the human thermal comfort situation in the Goller District (in the Mediterranean Region) of Turkey has been aimed. In the direction of the aim, the air temperature and relative humidity data of total 11 meteorology stations have been examined according to The Thermo-hygrometric Index (THI) and the New Summer Simmer Index (SSI). According to this, it has been determined that the thermal comfort conditions are not appropriate in the period of October-May on average monthly. The months of June and September are the most appropriate to almost all kinds of tourism and recreation activities in the outdoor in terms of thermal comfort. When THI and SSI indices' values are evaluated together, the periods between $5^{\text {th }}-$ $25^{\text {th }}$ June and $29^{\text {th }}$ August- $16^{\text {th }}$ September are the most appropriate periods in the study area on average in terms of the thermal comfort for the tourism and recreation activities in the outdoor.
\end{abstract}

Keywords: Thermal comfort, human health, The Thermo-Hygrometric Index, The Summer Simmer Index, Goller District, Turkey.

* ADDRESS FOR CORRESPONDENCE: Yuksel Guclu, Faculty of Education, Department of Social Studies Education, Sakarya University, Hendek, Sakarya, 54300, Turkey. E-mail address: yguclu@sakarya.edu.tr / Tel.: +90-533-727-4762 
Guclu, Y. (2016). Human Thermal Comfort Situation in the Goller (Lakes) District of Turkey, Global Journal on Advances in Pure \& Applied Sciences. [Online]. 07, pp 137-144. Available from: www.propaas.eu

\section{Introduction}

"The climate which is one and leading of many components of the inhabited environment forms direct and indirect effects on the human life and activities" [15]. "Since outdoor recreation is very weather sensitive, weather and climate can be one of the most important features attracting tourists, but also present limiting factors" [25]. For the people to continue their lives in a comfortable environment, the climate conditions are also required to be appropriate to this. In this context, the human thermal comfort has a big importance" [15].

"Thermal comfort is defined as the condition of mind that expresses satisfaction with the thermal environment (ASHRAE, 1992). Thermal comfort has very important effects on people performing outdoor recreation activities" [17]. "Variables of thermal comfort are the air temperature, radiant temperature, air velocity, relative humidity, activity and clothing" [24]. "There are several thermal comfort indexes which have been developed and widely used to evaluate human thermal comfort based on climatic variables such as air temperature, relative humidity, solar radiation, and wind speed as well as human factors like clothing and metabolism" [3]. "It expresses the real ambient temperature that is effectively being perceived by the human organism, under specified conditions of humidity and air temperature" [7]. "Because, although many factors are effective on the human thermal comfort, the temperature and humidity among them are effective in their wide areas [5] (www.bom.gov.au ,2012) and have effects on everybody" [15].

"It is known that the comfort feeling is subjective and there are different psychological and physical factors affecting this feeling. However, such kind of a study made on the human thermal comfort is interesting as it shows to what extent the climate conditions of the inhabited environment show average or optimum values in terms of climate conditions and it is also interesting in terms of determining the deviation measure from the average" [15]. "On the other hand, when it is considered that the human activities cannot be always limited to the spaces which are equipped air-conditioning systems such as buildings and vehicles, the importance of this situation is clearly understood" [15].

In this study, with reference to the above mentioned issues, it has been aimed to find an answer to the question of "How is the thermal comfort situation for human in the Goller (Lakes) District of Turkey?

\section{Material and Method}

\subsection{Study area and material}

Goller District takes place in the Antalya Subregion of the Mediterranean Region of Turkey. This area is called with this name due to the lakes of Acıgol, Egirdir, Beysehir, Burdur, Sugla, Salda, Yarıslı and Kovada (Figure 1). Goller District generally exhibits the transition area characteristics between the Mediterranean and Central Anatolian continental climate. With the natural, historical and cultural attractions that it possesses, the district shelters the locations appropriate for the tourism and recreational activities $[18,2,23,1,16,19,4]$. On the other hand, it is very near to the Southern Aegean and Western Mediterranean coasts which are of the most important $3 \mathrm{~S}$ tourism destinations of Turkey and world and it takes place on the route of the local and foreign tourists who want to reach to these areas via roadway. However, in spite of this huge potential, it has the attribution of being an area which cannot take adequate shares from the tourism. 


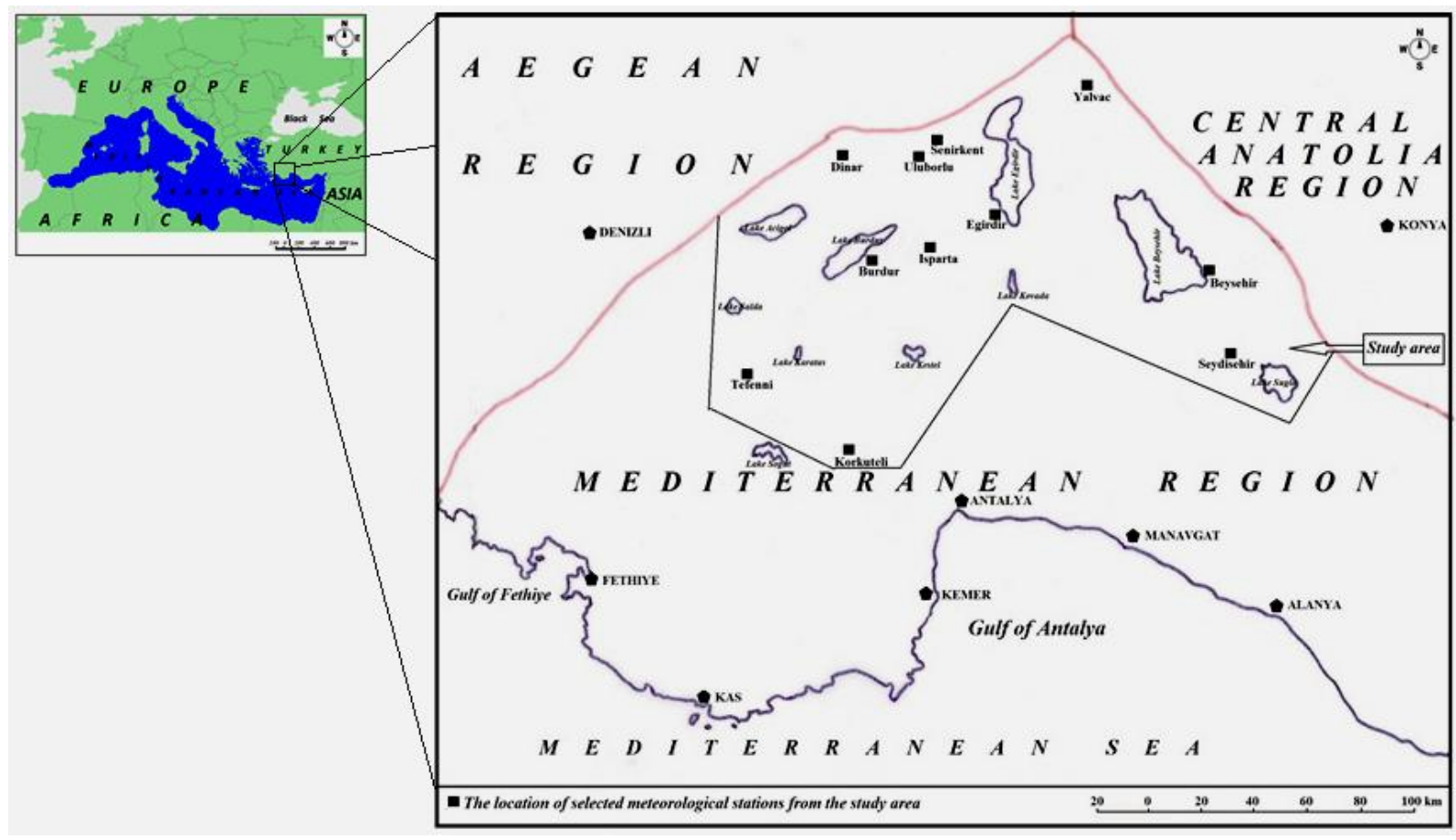

Figure 1. Location map of the study area

In this study, the average temperature and relative humidity data of totally 11 meteorology stations selected from the Goller District of Turkey (Figure 1) have been used. Required data were obtained from the Ministry of Forestry and Water Affairs, Turkish State Meteorological Service.

\subsection{Method}

Thermal comfort conditions were examined in accordance with Thermo-Hygrometric Index (THI) and The Summer Simmer Index. These indexes have been calculated by considering the simultaneous effect of the temperature and relative humidity. These indices used in the study are defined briefly below.

Thermo Hygrometric Index (THI): It employs a simple linear equation; $T H I=T-(0,55-0,0055 R H)(T$ 14, 5), where $\mathrm{T}$ is the air temperature in ${ }^{\circ} \mathrm{C}$ and $\mathrm{RH}$ is the relative humidity in \%. The $\mathrm{THI}$ is being classified according to Table 1.

Table 1. The categories of the Thermo Hygrometric Index [17].Table 1, pp 135

\begin{tabular}{ll}
\hline THI category & THI value $\left({ }^{\circ} \mathrm{C}\right)$ \\
\hline Hyper-glacial & $<-40$ \\
Glacial & -39.9 to -20 \\
Extremely cold & -19.9 to -10 \\
Very cold & -9.9 to -1.8 \\
Cold & -1.7 to +12.9 \\
Cool & +13 to +14.9 \\
Comfortable & +15 to +19.9 \\
Hot & +20 to +26.4 \\
Very hot & +26.5 to +29.9 \\
Torrid & $>+30$ \\
\hline
\end{tabular}


This index has been widely used especially in recent studies $[5,22,24,9,10,11,12,13,21,6,15,7$, $17,3]$.

The Summer Simmer Index (SSI): It employs a simple linear equation; SSI=1, 98 [Ta- (055-0,0055Ur) (Ta-58)]-56, 83 , where $\mathrm{Ta}$ is the air temperature in ${ }^{\circ} \mathrm{F}$ and $\mathrm{Ur}$ is the relative humidity in \% [20, 22]. The SSI is being classified according to Table 2 .

Table 2. The categories of the Summer Simmer Index [20]

\begin{tabular}{|c|c|c|}
\hline SSI value $\left({ }^{\circ} \mathrm{F}\right)$ & Zone & Cetegory properties \\
\hline $70-76$ & 1 & Most people are comfortable, but slightly cool \\
\hline $77-82$ & 2 & Nearly everyone feels quite comfortable \\
\hline $83-90$ & 3 & Most are comfortable, but slightly warm \\
\hline $91-99$ & 4 & Increasing discomfort is experienced (warm) \\
\hline $100-111$ & 5 & $\begin{array}{l}\text { A caution of sunstroke and heat exhaustion exists for prolonged exposure and } \\
\text { activity, along with significant discomfort (extremely warm) }\end{array}$ \\
\hline $112-124$ & 6 & $\begin{array}{l}\text { Virtually everyone is uncomfortable, a danger of heatstroke and great } \\
\text { discomfort exists (hot) }\end{array}$ \\
\hline $125-149$ & 7 & $\begin{array}{l}\text { There is an extreme danger of heatstroke, especially for the weakened or } \\
\text { elderly, and even young children, whose body metabolism demands cooler } \\
\text { effective temperatures than most adults. Maximum discomfort exists at these } \\
\text { conditions (extremely hot). }\end{array}$ \\
\hline Beyond 150 & 8 & Circulatory collapse is imminent for prolonged exposure \\
\hline
\end{tabular}

\section{Findings and discussion}

\subsection{Thermo Hygrometric Index (THI) findings}

THI values have been determined in the Goller District (Figure 1) on average monthly in months of May (except Beysehir), June and September in the "comfortable" category (Table 3, Table 1).

Table 3. Monthly status of THI categories in the Goller District (1987-2011 period)

\begin{tabular}{|c|c|c|c|c|c|c|c|c|c|c|c|c|}
\hline \multirow{2}{*}{$\begin{array}{c}\text { Meteorology stations } \\
\text { (Elevation) }\end{array}$} & \multicolumn{12}{|c|}{ THI categories and values according to months } \\
\hline & I & II & III & IV & $\mathrm{V}$ & VI & VII & VIII & $\mathrm{IX}$ & $x$ & $\mathrm{XI}$ & $X I$ \\
\hline Beysehir (1141 m) & 4,7 & 2,7 & 6,6 & 10,8 & 14,7 & 17,9 & 20,3 & 20,2 & 16,8 & 12,4 & 6,8 & 3,3 \\
\hline Burdur (957 m) & 4,5 & 5,5 & 8,4 & 12,2 & 16,3 & 19,7 & 22 & 21,8 & 18,5 & 14,3 & 9,3 & 5,6 \\
\hline $\operatorname{Dinar}(864 \mathrm{~m})$ & 4,3 & 4,4 & 7,5 & 11,4 & 15,5 & 19,2 & 21,6 & 21,3 & 17,7 & 13,3 & 8,2 & 5 \\
\hline Egirdir (920 m) & 4,7 & 5,6 & & & & & & & & & & \\
\hline
\end{tabular}


In the "comfortable" category which is the most appropriate period for the tourism and recreational activities to be realized in the outdoor, the THI values have been determined on approximately 83 days $(\% 22,7)$ between $11^{\text {th }}$ May $-25^{\text {th }}$ June and $29^{\text {th }}$ August $-5^{\text {th }}$ October.

According to the monthly averages in the months of July and August THI values are observed in the "Hot" category (Table 3). In the study area, the values are changing and the period in which the thermal comfort decreases and in which the THI values which are qualified as "hot" are observed is on average between $26^{\text {th }}$ June $-28^{\text {th }}$ August and it is approximately 64 days $(\% 17,5)$.

The THI values qualified as "cool" in the Goller District have been determined in the month of October (except Beysehir, Ulubuolu and Yalvac) and May-Beysehir (Figure1, Table 1). Between the $30^{\text {th }}$ April $-10^{\text {th }}$ May and $6^{\text {th }}$ October- $19^{\text {th }}$ October, it exhibits THI values in the "cool" category and the total duration is approximately 27 days $(\% 7,5)$.

As its degree changing, THI values take place in the "cold" category in October (Beysehir, Uluborlu and Yalvac) / November - April period (6 / 7 months) (Table 3). As the average of the study area, on approximately 191 days $(\% 52,2)$, between $20^{\text {th }}$ October - $29^{\text {th }}$ April, the THI values in the "cold" category have been determined. In this period, the winter tourism activities can be realized in the appropriate areas in the study area.

\subsection{The New Summer Simmer Index (SSI) findings}

According to the monthly averages, in Goller District (Figure 1), "Zone 1" is dominant in the month of June and September, "Zone 2" and "Zone 3" are dominant in the months of July and August. "Out of classification" category according to SSI data corresponds to the period of November-April (six months) on monthly average (Table 4, Table 2).

Table 4. Monthly status of SSI categories in the Goller District (1987-2011 period)

\begin{tabular}{|c|c|c|c|c|c|c|c|c|c|c|c|c|}
\hline \multirow{2}{*}{$\begin{array}{c}\text { Meteorology } \\
\text { stations (Elevation) }\end{array}$} & \multicolumn{12}{|c|}{ SSI categories and values according to months } \\
\hline & I & II & III & IV & V & VI & VII & VIII & $\mathrm{IX}$ & $x$ & $\mathrm{XI}$ & $X I$ \\
\hline Beysehir (1141 m) & 12 & 16 & 30 & 45 & 59 & 71 & 79 & 78 & 66 & 51 & 31 & 18 \\
\hline Burdur (957 m) & 22 & 26 & 37 & 50 & 64 & 77 & 85 & 84 & 72 & 58 & 40 & 26 \\
\hline Dinar (864 m) & 19 & 22 & 33 & 47 & 62 & 75 & 83 & 82 & 70 & 54 & 36 & 24 \\
\hline Egirdir (920 m) & 24 & 27 & 36 & 49 & 63 & 75 & 84 & 83 & 71 & 57 & 40 & 29 \\
\hline Isparta (997 m) & 20 & 24 & 34 & 47 & 62 & 74 & 83 & 82 & 70 & 55 & 37 & 24 \\
\hline Korkuteli (1017 m) & 24 & 27 & 36 & 48 & 62 & 75 & 82 & 82 & 71 & 56 & 39 & 28 \\
\hline Senirkent (957 m) & 19 & 24 & 36 & 50 & 64 & 75 & 83 & 83 & 70 & 55 & 36 & 25 \\
\hline Seydisehir (1129 m) & 13 & 17 & 33 & 48 & 62 & 74 & 83 & 83 & 71 & 54 & 34 & 20 \\
\hline Tefenni (1142 m) & 18 & 22 & 33 & 47 & 61 & 73 & 81 & 80 & 69 & 54 & 36 & 23 \\
\hline Uluborlu (1025 m) & 18 & 22 & 34 & 48 & 61 & 72 & 80 & 79 & 68 & 53 & 35 & 24 \\
\hline Yalvac (1096 m) & 14 & 17 & 30 & 45 & 60 & 71 & 81 & 81 & 68 & 51 & 32 & 19 \\
\hline Monthly average & & & & & & & & & & & & \\
\hline \multirow[t]{2}{*}{ THI value } & 19 & 22 & 34 & 48 & 62 & 74 & 82 & 82 & 70 & 54 & 36 & 24 \\
\hline & \multicolumn{4}{|c|}{ Out of classification } & \multicolumn{2}{|c|}{ Zone 1} & \multicolumn{2}{|c|}{ Zone 2} & \multicolumn{2}{|c|}{ Zone 3} & & \\
\hline
\end{tabular}


According to SSI index which is used in the determination of the real summer season duration, in the study area, totally 35 days $(\% 9,6)$ between $5^{\text {th }}$ June- $22^{\text {nd }}$ June and $1^{\text {st }}$ September- $16^{\text {th }}$ September are in "Zone 1 " category.

The SSI values in the "Zone 2" category are in Beysehir, Tefenni, Uluborlu and Yalvac and they are observed continuously on 60 days $(\% 16,4)$ between $30^{\text {th }}$ June $-28^{\text {th }}$ August and as intermittently for approximately 32 days $(\% 8,7)$ between $21^{\text {st }}$ June $-8^{\text {th }}$ July and $18^{\text {th }}$ August $-1^{\text {st }}$ September.

According to SSI index, the values in the "Zone 3" category are observed for approximately 40 days $(\% 10,9)$ between $9^{\text {th }}$ July $-16^{\text {th }}$ August in Burdur, Dinar, Egirdir, Isparta, Korkuteli, Senirkent and Seydisehir, and they are not observed in the other centres.

On the other hand, the values for approximately 263 day-period $(\% 71,9)$ are changing between $16^{\text {th }}$ September- $5^{\text {th }}$ June and they remain out of classification according to the SSI index.

\section{Conclusion}

When THI and SSI indices' values are evaluated together, the periods between $5^{\text {th }}-25^{\text {th }}$ June and $29^{\text {th }}$ August- $16^{\text {th }}$ September are the most appropriate periods in the study area on average in terms of the thermal comfort for the tourism and recreation activities in the outdoor. However, it can be said that in the period between $5^{\text {th }}$ June $-16^{\text {th }}$ September the thermal comfort conditions are generally appropriate.

The months of June and September are the most appropriate to almost all kinds of tourism and recreation activities in terms of thermal comfort.

The months of July and August are generally appropriate to the human health and activities in the outdoor. But, the months of July and August are the months in which the human thermal comfort significantly decreases due to the high temperature. At these months, it is recommended that the ones in the risk group such as mainly the ones having health problem, old persons, and children should care the type, level of the activities in the open areas and dresses as health problems can happen and they should avoid the heavy activities which will force especially the body. Also, it will be beneficial that the arising thermal comfort conditions should be announced to the persons living in the study area by using the appropriate and common communication tools and especially the ones in the risk group should be warned.

The human thermal comfort significantly decreases due to the low temperature and high relative humidity in the period of October-May as monthly average. In these periods, people should be provident against the situations which can threaten the human health. Especially the clothing should be cared and the activities which will compel the body should be avoided.

In the periods in which the climate comfort decreases in terms of the summer tourism which gets dense especially in the Southern Aegean and Western Mediterranean coasts [8, 11, 13, 14], the study area taking place in close proximity to these areas can be an important alternative tourism area. Especially due to being in high altitude, it exhibits more comfortable climate characteristics when compared to the coasts in the summer period.

\section{References}

[1] Alpar, O., \& Erdem, B., (2007). Turizmin Bolgesel Kalkinmaya Etkisi Cercevesinde Burdur Yoresinde Alternatif Turizmi Gelistirme Stratejileri, In: I. Burdur Sempozyumu Bildiriler, (Ed. Yıldırım, M. Z., Kazan, Spp 591599.

[2] Bingol, Z. (2004). Akdeniz Bolgesi'nde Alternatif Turizm Degerleri Cercevesinde Inanc ve Kultur Turizmi, Bilgi, 2004/1, 8, pp 125-137. 
Guclu, Y. (2016). Human Thermal Comfort Situation in the Goller (Lakes) District of Turkey, Global Journal on Advances in Pure \& Applied Sciences. [Online]. 07, pp 137-144. Available from: www.propaas.eu

[3] Din, M.F.M., Lee, Y.Y., Ponraj, M., Ossen, D.R., Iwao, K., \& Chelliapan, S., (2014). Thermal Comfort of Various Building Layouts with a Proposed Discomfort Index Range for Tropical Climate, Journal of Thermal Biology, 41, 6-15.

[4] Dinc, A., \& Ozturk, R., (2013). Beysehir Golu Milli Parkı'nın Ekoloji ve Turizm Bakımından Arastırıması, Turk Bilimsel Derlemeler Dergisi, 6(1), 118-123 (www.nobel.gen.tr.).

[5] Emmanuel, R., (2005). Thermal Comfort Implications of Urbanization in a Warm-Humid City: The Colombo Metropolitan Region (CMR), Sri Lanka, Building and Environment, 4O(12), 1591-1601.

[6] Gourabi, B.R., \& Palic, M., (2012). Recognition of Monthly Human Bioclimatic Comfort with Tourism Climate Index in Ramsar, South-West of Caspian Sea, Iran, AGD Landscape \& Environment, 6(1), 1-14.

[7] Grigore, E., (2013). Interannual Variation of the Average Values of Thermo- Hygrometer Index on the South Dobrogea Territory, Present Environment And Sustainable Development, 7(2), 215-223.

[8] Guclu, Y., (2008). The Determination of Sea Tourism Season According to the Climatic Conditions in Marmaris-Alanya Coastal Belt (SW of Turkey), Journal of Tourism Challenges and Trends, 1(2), 91-113.

[9] Guclu, Y., (2009). Batı Karadeniz Bolumu Kıyı Kusagında Klimatik Konfor ve Deniz Turizmi Mevsiminin İklim Kosullarına Gore Belirlenmesi (The Determination of Climate Comfortable and Sea Tourism Season According to the Climatical Conditions in The Western Black Sea Subregion Coastal Belt, Turk Cografya Dergisi, 53, 1-14.

[10] Guclu, Y., (2010). Sinop-Ordu Kıyı Kusagında İklim Konforu ve Deniz Turizmi Mevsiminin İklim Kosullarına Gore Belirlenmesi (The Determination of Climate Comfortable and Sea Tourism Season According to the Climatical Conditions on Sinop-Ordu Coastal Belt), Dogu Cografya Dergisi (Eastern Geographical Review), 15(23), 119-144.

[11] Guclu, Y., (2010). Ege Bolgesi Kıyı Kusagında İklim Konforu Sartlarının Kıyı Turizmi Yonunden İncelenmesi (The Examination of Climate Comfortable Conditions in Terms of Coastal Tourism on the Aegean Region Coastal Belt), International Journal of Human Sciences (Uluslararası Insan Bilimleri Dergisi) , 7(1), 794-823.

[12] Guclu, Y., (2010). Dogu Karadeniz Bolumu Kıyı Kusagında İklim Konforu Sartlarının Kıyı Turizmi Yonunden Incelenmesi, Cografi Bilimler Dergisi, 8(2), 111-137.

[13] Guclu, Y., (2010). Climate Comfortable Conditions for Coastal Toursim in the Coastal Belts of Turkey, 1 st ed. 2010, Istanbul. (In Turkish)

[14] Guclu, Y., (2011). Chapter Eleven: The Examination of Climate Comfortable Conditions in Terms of Coastal Tourism on the Mediterranean Coast of Turkey, In: Natural Environment and Culture in the Mediterranean Region II, Cambridge Scholars Publishing, (Ed. Efe, R., Ozturk, M., Atalay, I.), 123-136.

[15] Guclu, Y., (2012). Human Thermal Comfort Situation in the City of Sakarya, Turkey, Scottish Journal of Arts, Social Sciences and Scientific Studies, 7(1), 130-136.

[16] Gungor, S., \& Polat, A.T., (2007). Burdur Ilinin Turizm Ve Rekreasyon Planlaması Icin Iklim Istekleri Ve Iklim Konforu Analizi, In: I. Burdur Sempozyumu Bildiriler, (Ed. Yıldırım, M. Z., Kazan, S.), 618-626.

[17] Irmak, M.A., Yılmaz, S., Yılmaz, H., Ozer, S., \& Toy, S., (2013). Evaluation of Different Thermal Conditions Based on THI Under Different Kind of Tree Types - As a Specific Case in Ata Botanic Garden in Eastern Turkey, Global NEST Journal, 15(1), 131-139.

[18] Korkmaz, M., (2001). Orman Kaynaklarında Doga Turizmi Etkinliklerinin Ekonomik Cozumlemeleri (Kızıldag Milli Parkı Ornegi) (Economic Analysis of Ecotourism Activities in Forest Resources (The Sample of Kızıldag National Park), Suleyman Demirel Universitesi Orman Fakultesi Dergisi, 2, 111-134.

[19] Oztas, K., \& Karabulut, T., (2007). Turistik Destinasyon Olusturma Potansiyeli Acısından Goller Yoresinin Onemi (The Significance of Lakes District in Terms of Creating Touristic Destination), Selcuk Universitesi Karaman i.i.B.F., 12(9), 127-138.

[20] Pepi, J., W., (1999). The New Summer Simmer Index - A Comfort Index for the New Millennium.

[21] Sahin, K., (2010). The impact of climatic on 3S tourism in Samsun, Turkey: The summer 2008 experience, International Journal of Human Sciences, 7(1), 776-793.

[22] Tzenkova, A., Ivancheva, J., Koleva, E.,\& Videnov, P, (2007). The Human Comfort Conditions at Bulgarian Black Seaside, In: Developments in Tourism Climatology (Ed. Matzarakis, A., de Freitas, C. R., Scott, D.), 150-157. 
Guclu, Y. (2016). Human Thermal Comfort Situation in the Goller (Lakes) District of Turkey, Global Journal on Advances in Pure \& Applied Sciences. [Online]. 07, pp 137-144. Available from: www.propaas.eu

[23] Yılmaz, O., \& Yıldız, G., (2007). Burdur Illi'nin Turizm Potansiyeli, In: I. Burdur Sempozyumu Bildiriler (Ed. Yıldırım, M. Z., Kazan, S.), 569-590.

[24] Yilmaz, S., Toy, T., \& Yilmaz, H, (2007). Human Thermal Comfort Over Three Different Land Surfaces During Summer in The City of Erzurum, Turkey, Atmosfera, 20(3), 289-297.

[25] Zaninović, K., \& Matzarakis, A., (2007). Biometeorological Basis for Tourism", In, Developments in Tourism Climatology (Edit: Matzarakis, A., de Freitas, C. R., Scott, D.), 24-28 